\title{
Immunohistochemical and electron microscopic examination of Cajal cells in ureteropelvic junction obstruction
}

\author{
Alper Eken, MD, FEBU, ${ }^{*}$ Seyda Erdogan, MS, ${ }^{\dagger}$ Yurdun Kuyucu, MD; ${ }^{\ddagger}$ Gulsah Seydaoglu, MS, ${ }^{\ddagger}$ Sait Polat, MD; ${ }^{\xi}$ \\ Nihat Satar, $M D^{*}$
}

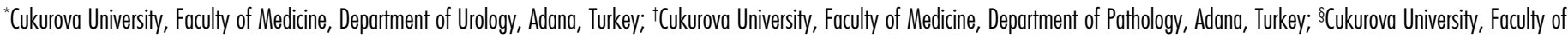
Medicine, Department of Histology and Embryology, Adana, Turkey; ‘Cukurova University, Faculty of Medicine, Department of Biostatistics, Adana, Turkey

Cite as: Can Urol Assoc J 2013;7(5-6):e311-6. http://dx.doi.org/10.5489/cuaj.11293 Published online May 13, 2013 (early released September 10, 2012).

\section{Abstract}

Objective: We examine the ultrastructural configurations of Cajal cells by electron microscopy, as well as the quantitative changes occurring in Cajal cells by light microscopy.

Methods: In total, 35 patients with ureteropelvic junction (UPJ) obstruction and 7 patients without obstruction were compared immunohistochemically with c-kit (CD117) to quantify the number of cells. On electron microscopic examination, 7 patients with UPJ obstruction and 3 patients without obstruction were compared to evaluate the changes which occurred in the ultrastructural configuration of the Cajal cells.

Results: On light microscopic examination, it was determined that the Cajal cells, which demonstrate c-kit (CD117) immunoreactive character, were located near the circular muscle layer and parallel to the muscle cells. The number of Cajal cells in the control group was significantly increased compared to the number of cells in patients with UPJ obstruction $(p<0.001)$. On electron microscopic examination, the number of interstitial cells was also higher in the control group. A decrease in the number of the caveolae in these cells was seen in the group with UPJ obstruction compared to the control group.

Conclusion: In UPJ obstruction, a decrease in the number of Cajal cells, as well as the changes in the morphologic structure of the Cajal cells, indicates that these cells have a role in the pacemaker system and are associated with ureteral peristalsis.

\section{Introduction}

Interstitial cells of Cajal (ICC) were first described as "neuron-like cells" at the motor neuron endings. ${ }^{1}$ The hypothesis was advanced by Thuneberg, who suggested that these cells had pacemaker activity in the intestine, as in the heart. These cells have gap junctions with smooth muscle cells which give way to nerve terminals; these these cells are called pacemaker cells. $^{2}$
Although the embryologic origin is unclear, it has been shown that interstitial cells originate from the mesenchymal cells. ${ }^{3}$

The finding that Cajal cells express c-kit (CD117), a tyrosine kinase, is a considerable development. The c-kit is a membrane receptor protein, a growth factor and a protooncogene. It consists of an external ligand binding component and a cytoplasmic tyrosine kinase component. ${ }^{4}$

In several disorders of gastrointestinal motility, including Hirschsprung's disease, chronic intestinal pseudo-obstruction, slow transit constipation abnormalities are observed in the density and distribution of the c-kit positive cells. ${ }^{5-7}$

The renal calyces, renal pelvis, UPJ, ureters (proximal to distal), ureteral orifices, fundus and corpus of the bladder in porcines were evaluated by Metzger and colleagues. ${ }^{8} \mathrm{c}$-kit expression was examined at the level of mRNA in ureteral tissue and the highest expression of c-kit mRNA was determined to be in the UPJ. ${ }^{9}$ Similarly, the authors studied ICC in the human upper urinary system and 56 ureters were examined. A slight decrease was determined in the numbers of cells along the ureteral segments from the proximal to the distal parts. ${ }^{8}$

C-kit immune positive-stained cells have also been demonstrated in the urinary bladder, urethra, prostatic stroma, vas deferens, corpus cavernosum and spermatogonia. ${ }^{10-15}$

We investigate the quantitative and ultrastructural changes of ICC UPJ obstruction using light and electron microscopy.

\section{Methods}

In total, 52 patients were included in the study. Of this total number, 42 patients were examined by immunohistochemical methods: 35 patients with UPJ obstruction (median age 36 months) and 7 patients without obstruction (median age 348 months). Ten patients who had undergone nephrectomy for other reasons (renal tumor, trauma etc.) without obstruc- 
tion served as the control group. Of these 10, the specimens of 7 patients with UPJ obstruction (median 9 months) and 3 patients without obstruction (median 600 months) were examined by electron microscopy for the ultrastructural configuration. We obtained written informed consent from all patients (Cukurova University, TF2006LTP12).

\section{Immunohistochemical staining}

Tissues, $2 \mathrm{~cm}$ in length and including the UPJ, were obtained from the cases with obstruction. In the non-obstruction group, the area in which the renal pelvis is narrowed and cone-shaped and continues as the ureter was used and a 0.5-1 cm tissue sample was obtained.

Tissues were fixed in $10 \%$ formaldehyde solution and the fixation procedure was completed with an autotechnicon device (Shandon Southern Instruments Ltd, UK). Sections, 4-5 $\mu$ in thickness, were obtained from the paraffin-embedded tissues. The slides were kept in distilled water containing $0.3 \mathrm{w} / \mathrm{v} \mathrm{H}_{2} \mathrm{O}_{2}$ for 7 minutes and washed. The samples were put in an EDTA buffer solution $(\mathrm{pH} 8)$ and boiled in a microwave oven $(600 \mathrm{~W})$ for 15 minutes as an antigen-retrieval procedure. The slides were kept covered and washed with distilled water and phosphate buffered saline (PBS; $\mathrm{pH} 7.2$ 7.4). Primary antibody (NCL-L-CD117; Novocastra Ltd, UK), diluted 1/50, was dripped on the slides. After incubation, the slides were washed with distilled water and PBS. Biotin and Avidin (Universal Dako LSAB $®+$ Kit, USA) was dripped on the slides, and the slides were incubated at room temperature for 30 minutes and washed. An aminoethylcarbizole (AEC) peroxidase chromogen kit (Daco Corporation, Carpinteria, CA) was dripped on the slides and viewed at 10- to 20-minute intervals and put into tap water as soon as staining was observed. The slides were washed and put into hematoxylene for 10 minutes, and placed in tap water for about 10 minutes. The tissue was dried and covered with an aqueous-based mounting media.

\section{Evaluation of immunohistochemical staining}

C-kit was evaluated under the light microscope using a Nikon Eclipse 80 i. Sections were examined with a microscope under $100 \times, 200 \times$ and $400 \times$ magnifications. Ten large magnification areas were counted in the same specimen from each case, and the number of Cajal cells was quantitatively determined. The densities of the c-kit positive cells were calculated by screening 10 areas separately. According to their total number in the areas, Cajal cells were identified as follows: $0-3$ cells, sparse; 4-8 cells, few; and $>8$ cells, many. The results are presented as the mean \pm standard deviation, median, number and percentage.

\section{Electron microscopy methods}

After keeping samples in 5\% glutaraldehyde solution prepared with Millonig's phosphate buffer ( $\mathrm{pH}$ 7.4) for 1 hour, samples were transferred into Petri dishes, which included a few drops of $5 \%$ glutaraldehyde, covered with paraffin, and separated into about $1 \mathrm{~mm}^{3}$ pieces. The samples were put into 5\% glutaraldehyde solution and fixed for 3 hours. Tissues were put into Millonig's overnight. Tissues were transferred to a $1 \%$ solution of osmium tetraoxide prepared with Millonig's, fixed for 2 hours, and then washed two times with Millonig's. Tissues were dehydrated at $+4^{\circ} \mathrm{C}$ by processing with gradually increasing alcohol series $(50 \%$ to $100 \%$ ) at 15 -minute intervals. Tissues were kept then in propylene oxide for 30 minutes. Dehydrated samples were then immersed in propylene oxide and embedding material. Samples were transferred to tubes, including fresh prepared embedding material (Ciba Ltd, UK) and stirred on a rotator overnight. The samples were embedded in 00 polyethylene capsules using fresh embedding material and polymerized in a $60^{\circ} \mathrm{C}$ incubator for 48 hours. Five hundred $\mathrm{A}^{\circ}$ sections were obtained from the blocks. Sections were collected on copper grids with 200-300 pores and stained with saturated uranyl acetate solution in 70\% ethyl alcohol and Reynolds' lead citrate solution. The stained sections were examined with a Jeol JEM 1400 transmission electron microscope.

\section{Statistical evaluation}

Statistical analyses were performed using a SPSS. A chisquare test was applied for the calculation of categorical variables, whereas the Mann-Whitney $U$ test was applied for a comparison of the mean values. A significance level of $p<0.05$ was used.

\section{Results}

The specimens of 35 patients with obstruction (median age 36 months) and 7 patients without obstruction (median age 348 months) were examined immunohistochemically (Table 1). Specimens from 7 patients with UPJ obstruction (median 9 months) and 3 patients without obstruction (median 600 months) were examined with an electron microscope (Table 2).

\section{Light microscope and immunohistochemical results}

C-kit positive-stained cells were located near the circular muscle layer and parallel to the muscle fibres, which were easily distinguished from the mast cells with spindle-like and dentritic extensions, a granular cytoplasm and an oval nucleus (Fig. 1, Fig. 2). 


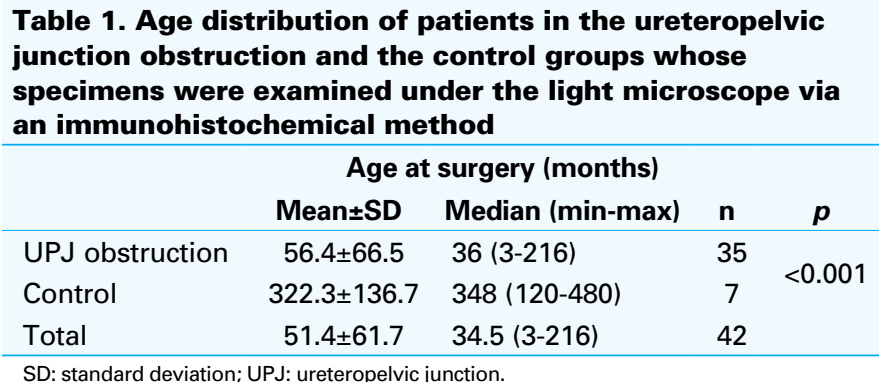

Ten large magnification areas were counted after immunohistochemical staining and the number of ICC were quantitatively assessed. The mean distribution of the cells, the standard deviation and minimum and maximum values were calculated. It was determined that the Cajal cells were encountered more frequently in the control group. A maximum of 3 Cajal cells were counted on the examined sections obtained from the patients with obstruction, whereas up to 7 cells were counted on those obtained from the control group. The ratio of areas with no cells in the UPJ obstruction group was significantly higher when compared to the control group.

The number of cells in 10 separately screened areas was calculated and the total number of Cajal cells in the areas, $0-3,4-8$, and $>8$ cells were regarded as sparse, few and many, respectively. The cell count in the group with UPJ obstruction was sparse in 8 patients $(22.9 \%)$, few in 26 patients $(74.3 \%)$ and many in 1 patient $(2.9 \%)$. In the control group $>8$ cells were detected in all patients. When these results were compared, the difference was statistically significant $(p<0.001)$ (Table 3, Fig. 3).

\section{Electron microscopic results}

Interstitial Cajal-like cells were observed in the lamina propria and muscular layer. Although these cells were comparable to fibroblasts, they had thinner, longer and more uni-

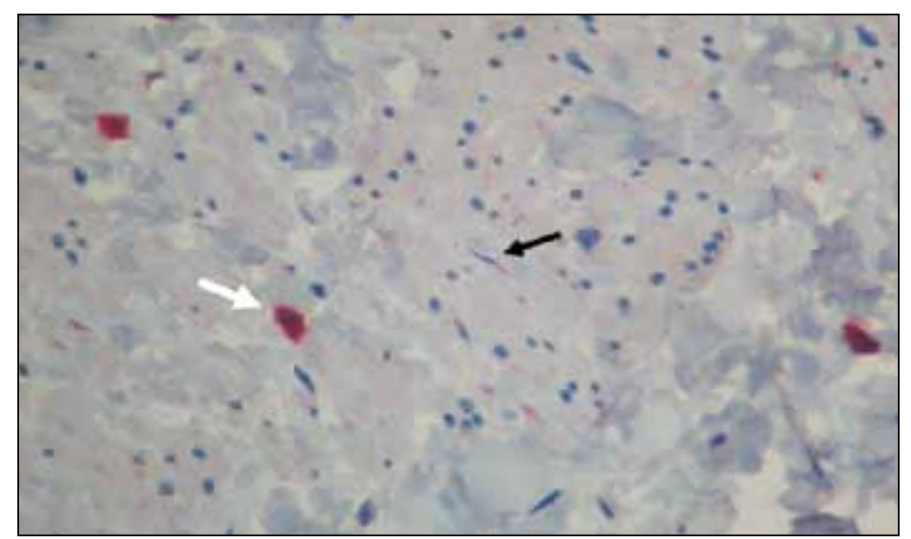

Fig. 1. C-kit (CD117) positive-stained mast cells (white arrow) and Cajal cell with cytoplasmic extension between muscle fibres from a control patient (black arrow; CD117, 400x).

\begin{tabular}{|c|c|c|c|c|c|}
\hline & \multicolumn{5}{|c|}{ Age at surgery (months) } \\
\hline & Mean \pm SD & Median & Minimum & Maximum & $\mathbf{n}$ \\
\hline $\begin{array}{l}\text { UPJ } \\
\text { obstruction }\end{array}$ & $51.86 \pm 77.508$ & 9.00 & 4 & 184 & 7 \\
\hline Control & $\begin{array}{c}568.00 \\
\pm 77.149\end{array}$ & 600.00 & 480 & 624 & 3 \\
\hline Total & $\begin{array}{c}206.70 \\
\pm 259.785\end{array}$ & 77.00 & 4 & 624 & 10 \\
\hline
\end{tabular}

SD: standard deviation; UPJ: ureteropelvic junction.

formly bounded nucleus and the cytoplasm was quite thin as well as less developed with respect to organelles. The thin cytoplasmic extensions penetrated the smooth muscle cells. A limited number of cell organelles and the presence of thin filaments were noticed in the cytoplasmic extensions. The cytoplasmic extensions formed connections with each other, and with connective tissue in the form of hemidesmosomes. Although in some areas, these interstitial Cajal-like cells were observed to have basal lamina like homogenous and noncontinuous extracellular substance deposition, it was realized that these cells generally do not have a distinct basal lamina similar with the fibroblasts (Fig. 4, Fig. 5).

In the obstruction group, the frequency of these cells was relatively less. The cytoplasm was abundant in these enlarged parts and contained a limited number of granular endoplasmic reticulum cisternae and mitochondria (Fig. 6, Fig. 7).

\section{Discussion}

c-kit positive Cajal cells, which are easily distinguished from the mast cells in the UPJ, were demonstrated in this study. ICC in the UPJ had spindle-like fusiform extensions, oval nucleus and granular cytoplasm and located parallel to the muscle fibres in the circular muscular layer. In non-obstruct-

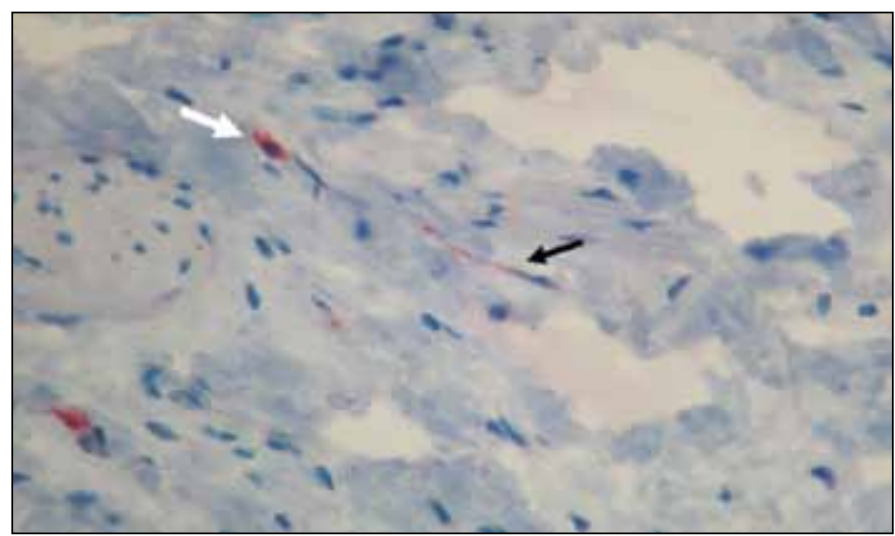

Fig. 2. C-kit positive-stained mast cells (white arrow) and Cajal cell with spindle-like cytoplasmic extension from a control patient (black arrow; CD117, $400 \times)$. 
Table 3. Distribution of the patients in the ureteropelvic junction obstruction and control groups according to the total cell count performed by means of an immunohistochemical method

\begin{tabular}{|c|c|c|c|c|c|c|c|c|}
\hline & \multicolumn{3}{|c|}{ Density } & \multicolumn{5}{|c|}{ Total Cell } \\
\hline & $\begin{array}{c}\text { Sparse (0-3) } \\
\text { n (\%) }\end{array}$ & $\begin{array}{c}\text { Few (4-8) } \\
\text { n (\%) }\end{array}$ & $\begin{array}{c}\text { Many (>8) } \\
\text { n (\%) }\end{array}$ & $p$ & Mean \pm SD & Median (min-max) & $\mathbf{n}$ & $p$ \\
\hline UPJ obstruction & 8 (22.9) & $26(74.3)$ & $1(2.9)$ & \multirow{3}{*}{$<0.001$} & $5.2 \pm 2.1$ & $6(0-9)$ & 35 & \multirow{3}{*}{$<0.001$} \\
\hline Control & $0(0)$ & $0(0)$ & $7(100)$ & & $22.7 \pm 12.7$ & 19(9-39) & 7 & \\
\hline Total & $8(19.0)$ & $26(61.9)$ & $8(19)$ & & $8.1 \pm 8.4$ & $6(0-39)$ & 42 & \\
\hline
\end{tabular}

SD: standard deviation; UPJ: ureteropelvic junction.

ed group, compared to obstructed samples, a large number of c-kit positive cells was seen $(p<0.001)$. In obstructed group, c-kit positive cells were sparse or absent.

The pathophysiology of congenital UPJ obstruction is controversial. There are many explanations for the decrease in the extension ability of the narrow segments, which lead to the functional discontinuity of ureteropelvic muscle contractions: disorders in muscular structure, atrophy or a decrease in the number of smooth muscle cells, a decrease in the number of ICC and nerve endings, and an increase in the collagen deposits between the muscular clusters. ${ }^{16,17}$ Some researchers consider the intrinsic function disorder as the underlying mechanism of the obstruction, and suggest that morphologic changes are secondary. ${ }^{18}$

Pacemaker cells which demonstrate spontaneous depolarization and are electrically associated with ureteral smooth muscle cells are required for pyeloureteral peristalsis. Following renal transplantation, pyeloureteric-ureteric surgery or obstruction, important findings include: in vitro observations of spontaneous activation in human or pig ureters in which the connection with the renal pelvis has been disconnected and in vivo observations of spontaneous activation of peristaltic waves of rudimentary ureters. ${ }^{19}$

Although myogenic and neurogenic mechanisms play a role in the ureteral peristalsis, the presence of specialized cells in association with these two structures is needed. Specialized atypical smooth muscle cells in the upper uri-

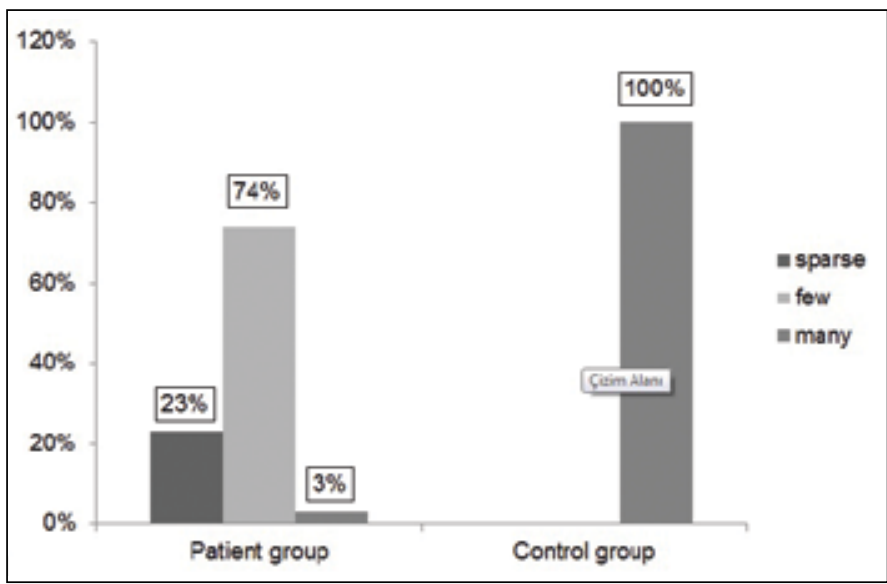

Fig. 3. Percentage of cells in patients with ureteropelvic junction obstruction and the control group. nary system, which are in close association with each other and with smooth muscle cells, have been thought to be the pacemaker cells. This histologically-defined pacemaker network is placed along the ureteral muscle layer and is gradually decreased in number from the proximal to the distal parts of the ureter. ${ }^{20}$

To investifate the the significance of interstitial cells in the upper urinary system, prepared tissue cultures have been inoculated in ACK 45, which has an antibody characteristic against c-kit and neutralizes its activity. In all of the specimens, including the c-kit neutralizing antibody, one-way peristalsis decreased. In addition, gross structural changes were observed in the ureters cultured in the media including antibodies. ${ }^{21}$

Solari and colleagues investigated the expression of c-kit positive cells in the congenital UPJ obstruction. Fusiform cells had large, oval-shaped nuclei with a small amount of nucleoplasm and two dentritic extensions, whereas the mast cells had round, central nuclei. Although there were too many c-kit positive cells in the UPJ of the control group,

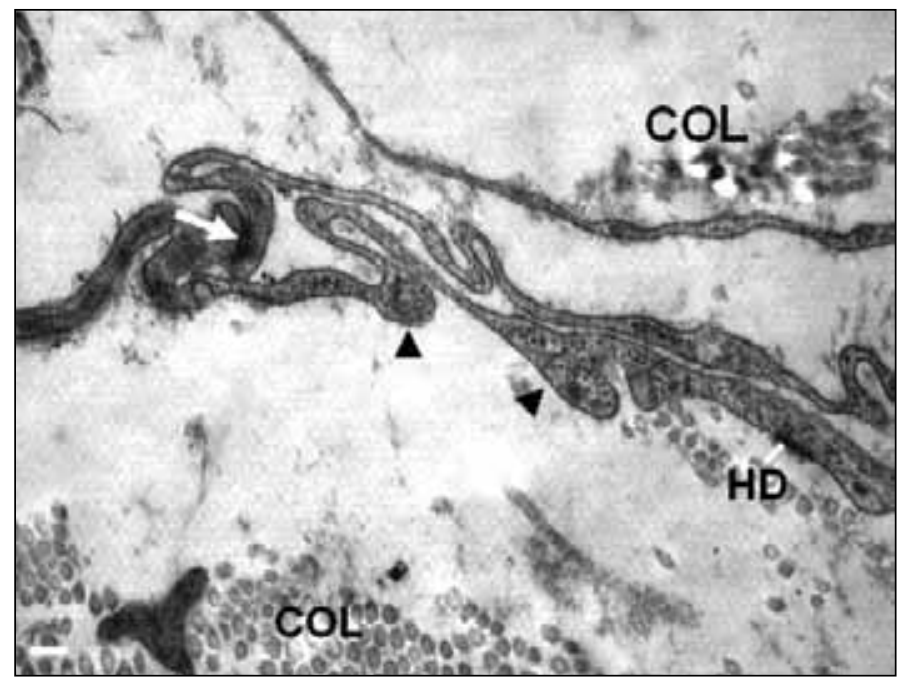

Fig. 4. Interstitial Cajal-like cellular extensions were observed in the lamina propria. It was observed that the cytoplasmic extensions demonstrate local enlargements along their course (heads of the arrows) and curled as a labyrinth. It was also observed that the extensions are connected to each other with connection complexes in some areas (arrows). Hemidesmosome formation, which was observed along the collagen fibres and extensions, was demonstrated. 


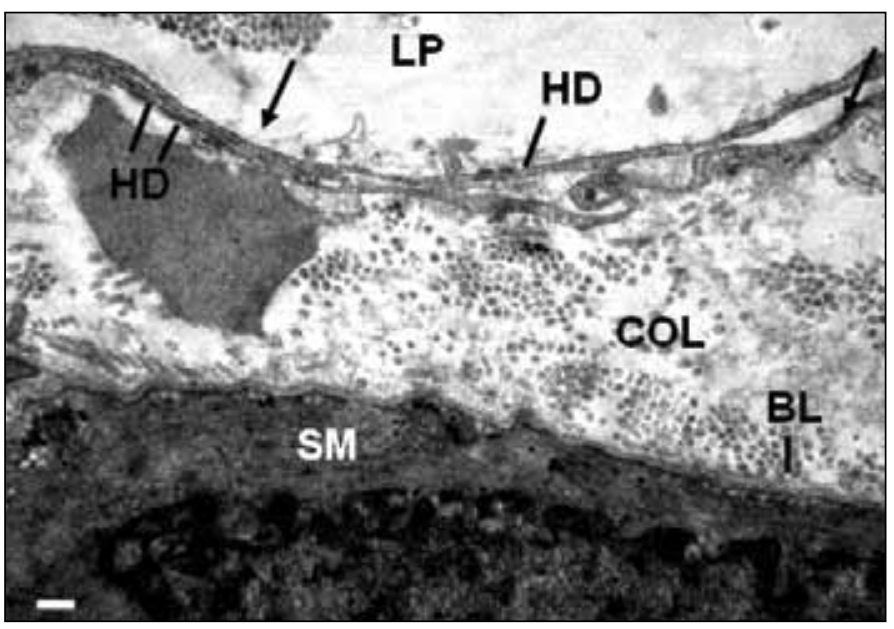

Fig. 5. Control group. Interstitial Cajal-like cell extensions located at the border between the smooth muscle layer and lamina propria were observed (arrows). Hemidesmosome formation, which was observed along the cytoplasmic extensions, and the basal lamina located around the collagen fibres and smooth muscle were demonstrated.

there were fewer or none in those with UPJ obstruction $(p<0.05) .{ }^{16}$

Yang and colleagues studied the expression and significance of ICC at the obstruction site of congenital pelviureteric junction obstruction. Immunoreactivity to ICC was predominantly detected in the muscle layers. The authors found a decreased mean density of ICC expression in the UPJ obstruction group which was lower than in the control group..$^{22}$

Our results correlate with ones by Solari ${ }^{16}$ and Yang. ${ }^{22}$ We observed the presence of similar c-kit positive cells in our study. These two studies, similar to our study, showed decreased density of ICCs in the UPJ obstructed specimens. The absence or reduction of ICC was seen in some gastrointestinal motility disorders, such as Hirschsprung's disease, chronic intestinal pseudo-obstruction or slow transit constipation..$^{5-7}$ Based on the gastrointestinal motility disorders and these two studies, decreased density of ICC or abnormality in ICC may play a role in the pathogenesis of UPJ obstruction. It is, however, difficult to answer whether the observed changes in ICC are the primary cause of the disorder or a secondary effect.

Kuzgunbay and colleagues examined the changes in the number and morphologies of Cajal-like cells in the UPJ of the rats that undergone an experimental distal ureter ligation. ${ }^{23}$ They found increased numbers of interstitial Cajallike cells in the submucosal layer of the UPJ 7-90 days after distal ureteral obstruction. The peak value occurred on the $14^{\text {th }}$ day and a decline was detected, and the level reached a plateau phase. The authors emphasized that the initial increase might be due to the response against increased peristaltic activity or due to the increase in precursors. They also indicated that the decrease in cell number in further stages

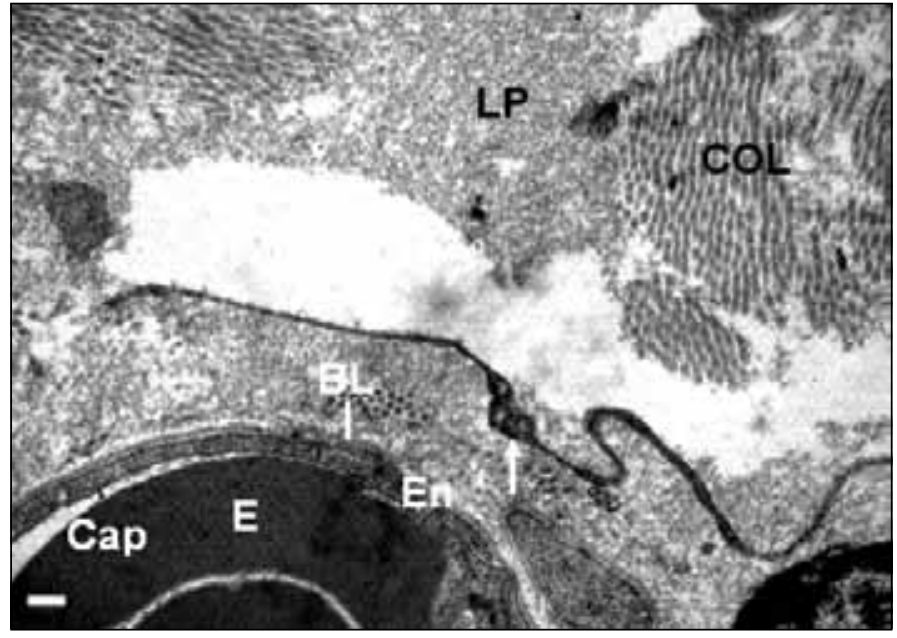

Fig. 6. Interstitial Cajal-like cell extension located close to the capillary vessel was observed in the lamina propria (arrow). It was observed that the endothelial cell located in the capillary vessel wall has been surrounded by a distinct basal lamina. Erythrocyte in the capillary vessel and the collagen fibres in the connective tissue were demonstrated.

resulted from the decrease in peristaltic activity, but a slight increase in cell number compared to the beginning was due to the prolonged neuromodulator roles. It differs from the present study in terms of the localization of the obstruction and its association with time. However, a decrease in the number of ICC with decreased peristaltic activity might be considered a common point. ${ }^{23}$

Koleda and colleagues studied the density of interstitial cells in ureteropelvic junction obstruction. ${ }^{24}$ The number of fields with few ICC (0-1) was significantly lower in obstructed group than non-obstructed group. Additionally, the number of fields with dense ICC (4-8) was significantly higher in obstructed cases than in normal UPJ. The number of ICCs decreased with increasing age of the patients with obstruction..$^{24}$ These observations differ from Solari, ${ }^{16}$ and Yang ${ }^{22}$ and our study. Der ${ }^{25}$ and Chang ${ }^{26}$ suggested that small intestine inflammation or obstruction occurs with a decrease in ICC; they also indicated that ICC are restored removing the obstruction or treating the inflammation. Yang and colleagues ${ }^{22}$ indicated that ICC abnormalities that are seen in some disorders are clearly related to a developmental delay of these cells and may be a "bystander" effect, and possibly still contribute to the pathogenesis of the disorder.

We have two major limitations in our study. The first one is that very few patients were examined in the control group. The second limitation is the difference in age distribution between the obstructed and non-obstructed groups; this occurred because patients with unaffected UPJ, like Wilms tumour, are rarely treated at our institution. Gomez-Pinilla and colleagues ${ }^{27}$ showed that the number of c-kit positive cells in the colon and stomach decreased with increased age. If this is the case, we may have found higher number of c-kit positive cells in the younger control group since in 


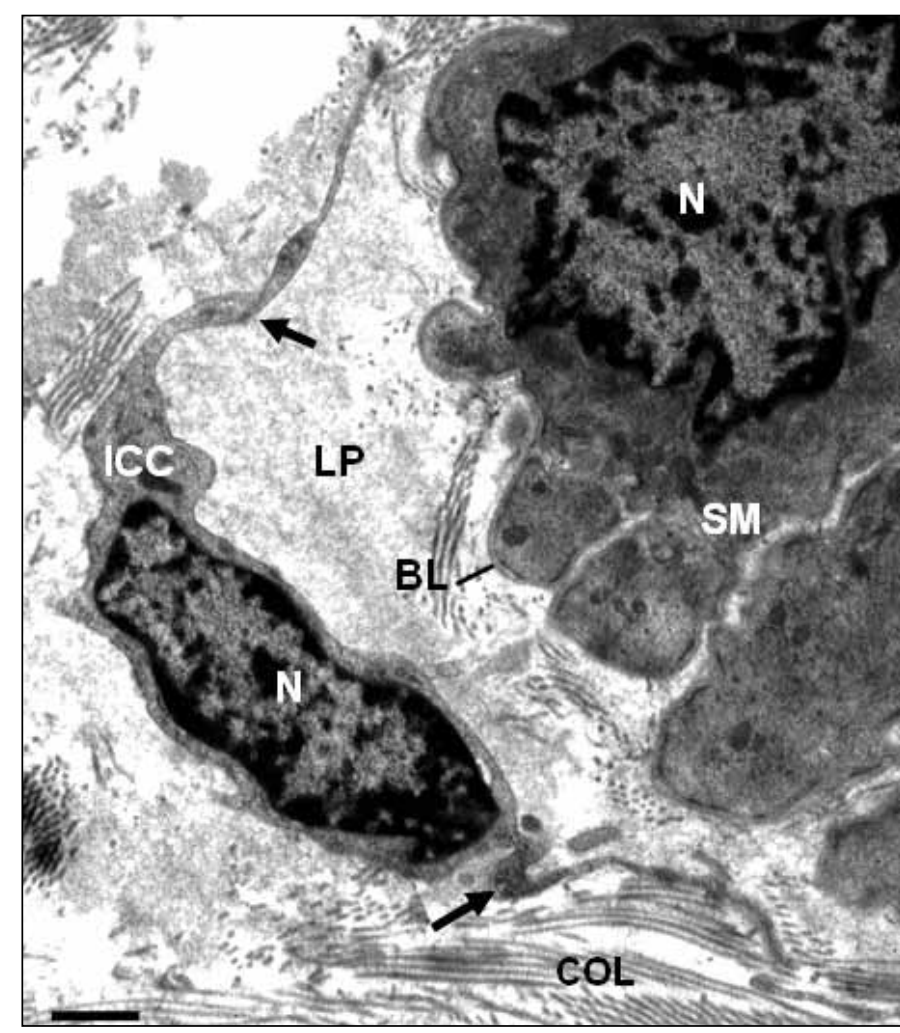

Fig. 7. Interstitial Cajal-like cells located close to the smooth muscle layer were observed in the lamina propria. An oval-shaped nucleus in the cell and a limited number of organelles in the cytoplasm were observed. Extensions from the opposite poles of the cell were noted (arrows). The nucleus and cytoplasm of the smooth muscle cells in the muscular layer were normal, and the cells have a distinct external basal lamina.

our study they were much older than the obstructed group of patients.

\section{Conclusion}

Although the ultrastructural configurations in the gastrointestinal and neuronal systems have frequently been evaluated via electron microscopic methods, studies about the electron microscopic evaluation of Cajal cells in human UPJs have not been encountered in the literature. Electron microscopic studies performed on age-controlled cases are needed to better understand UPJ pathophysiology.

Competing interests: None declared.

This paper has been peer-reviewed.

\section{References}

1. Cajal SR. Histologie du système nerveux de l'homme et des vertébrés. Maloine (Paris) 1911;2:891-942.

2. Thuneberg L. Intersititial cells of Cajal: intestinal pacemaker cells? Adv Anat Embryol Cell Biol 1982;71:1130. http://dx.doi.org/10.1007/978-3-642-68417-3_1
3. Young HM. Embryological origin of interstitial cells of Cajal. Microsc Res Tech 1999;47:303-8. http:// dx.doi.org/10.1002/(SICI) 1097-0029(19991201)47:5<303::AID-JEMT1>3.0.C0;2-T

4. Maeda $\mathrm{H}$, Yamagata A, Nishikawa $\mathrm{S}$, et al. Requirement of c-kit for development of intestinal pacemaker system. Development 1992;116:369-75.

5. Yamataka $A$, Kato $Y$, Tibboel D, et al. A lack of intestinal pacemaker (c-kit) in aganglionic bowel of patients with Hirschsprung's disease. J Pediatr Surg 1995;30:441-4. http://dx.doi.org/10.1016/00223468(95) $90051-9$

6. Yamataka A, Ohshiro K, Kobayashi H, et al. Abnormal distribution of intestinal pacemaker (C-KIT-positive) cells in an infant with chronic idiopathic intestinal pseudoobstruction. J Pediatr Surg 1998;33:859-62. http://dx.doi.org/10.1016/S0022-3468(98)90660-1

7. Vanderwinden JM, Liu H, Laet MHD, et al. Study of the interstitial cells of Cajal in infantile hypertrophic pyloric stenosis. Gastroenterology 1996;111:279-88. http://dx.doi.org/10.1053/gast.1996.v111. pm8690192

8. Metzger R, Schuster T, Till H, et al. Cajal-like cells in the human upper urinary tract. J Urol 2004;172:76972. http://dx.doi.org/10.1097/01.ju.0000130571.15243.59

9. Metzger R, Neugebauer A, Rolle U, et al. C-Kit receptor (CDI 17) in the porcine urinary tract. Pediatr Surg Int 2008; 24:67-76. http://dx.doi.org/10.1007/s00383-007-2043-2

10. Wiseman $0 \mathrm{~J}$, Fowler CJ, Landon DN. The role of the human bladder lamina propria myofibroblast. BJU Int 2003;91:89-93. http://dx.doi.org/10.1046/i.1464-410X.2003.03802.x

11. Van der Aa F, Roskams T, Blyweert W, et al. Identification of kit positive cells in the human urinary tract. J Urol 2004;171:2492-6. http://dx.doi.org/10.1097/01.ju.0000125097.25475.17

12. Van der Aa F, Roskams T, Blyweert W, et al. Interstitial cells in the human prostate: A new therapeutic target? Prostate 2003;56:250-5. http://dx.doi.org/10.1002/pros.10264

13. Metzger R, Rolle U, Fiegel HC, et al. C-kit receptor in the human vas deferens: distinction of mast cells, interstitial cells and interepithelial cells. Reproduction 2008;135:377-84. http://dx.doi.org/10.1530/ REP-07-0346

14. Shafik A. Study of intersititial cells in the penis: human study. J Sex Med 2007;4:66-71. http://dx.doi. org/10.1111/j.1743-6109.2006.00397.x

15. Orth JM, Jester WF, Qiu J. Gonocytes in testes of neonatal rats. Mol Reprod Dev 1996;45:123-31. http:// dx.doi.org/10.1002/(SICI) 1098-2795(199610)45:2<123::AID-MRD3>3.0.C0;2-V

16. Solari V, Piotrowska AP, Puri P. Altered expression of interstitial cells of Cajal in congenital ureteropelvic junction obstruction. J Urol 2003;170:2420-2. http://dx.doi.org/10.1097/01.ju.0000097401.03293.f0

17. Murakumo $M$, Nonomura $K$, Yamashita $T$, et al. Structural changes of collagen components and diminution of nerves in congenital ureteropelvic junction obstruction. J Urol 1997;157:1963-8. http://dx.doi. org/10.1016/S0022-5347(01)64910-3

18. Truong LD, Choi YJ, Tsao CC, et al. Renal cell apoptosis in the chronic obstructive uropathy: the roles of caspases. Kidney Int 2001;60:924-34. http://dx.doi.org/10.1046/i.1523-1755.2001.060003924.x

19. Lang RJ, KLemm MF. Interstitial cell of Cajal-like cells in the upper urinary tract. J Cell Mol Med 2005;9:543-56. http://dx.doi.org/10.1111/j.1582-4934.2005.tb00487.x

20. Gosling JA, Dixon JS. Species variation in the location of upper urinary tract pacemaker cells. Invest Urol 1974;11:418-23.

21. David SG, Cebrain C, Vaughan ED, et al. C-kit and ureteral peristaltis. J Urol 2005;173:292-5. http:// dx.doi.org/10.1097/01.ju.0000141594.99139.3d

22. Yang X, Zhang Y, Hu J. The expression of Cajal cells at the obstruction site of congenital pelviureteric junction obstruction and quantitative image analysis. J Pediatr Surg 2009;44:2339-42. http://dx.doi. org/10.1016/i.jpedsurg.2009.07.061

23. Kuzgunbay B, Doran $F$, Bayazit $Y$, et al. The effects of ureteral obstruction on Cajal-like cells in rats. J Pediatr Urol 2009;5:269-73. http://dx.doi.org/10.1016/i.jpurol.2008.12.006

24. Koleda P, Apoznanski W, Wozniak Z, et al. Changes in interstitial cell of Cajal-like cells density in congenital ureteropelvic junction obstruction. Int Urol Nephrol 2012;44:7-12. http://dx.doi.org/10.1007/ s11255-011-9970-5

25. Der T, Bercik P, Donnelly $G$, et al. Interstitial cells of Cajal and inflammation-induced motor dysfunction in the mouse small intestine. Gastroenterology 2000;119:1590-9. http://dx.doi.org/10.1053/ gast.2000.20221

26. Chang IY, Glasgow NJ, Takayama I, et al. Loss of interstitial cells of Cajal and development of electrical dysfunction in murine small bowel obstruction. J Physiol 2001;536:555-68. http://dx.doi. org/10.1111/i.1469-7793.2001.0555c.xd

27. Gomez-Pinilla PJ, Gibbons SJ, Sarr MG, et al. Changes in interstitial cells of Cajal with age in the human stomach and colon. Neurogastroenterol Motil 2011;23:36-44. http://dx.doi.org/10.1111/i.13652982.2010.01590.x

Correspondence: Dr. Alper Eken, University of Cukurova, Faculty of Medicine, Department of Urology, 01330, Adana, Turkey, fax: +90 322 4573072; alpereken@yahoo.com 